\title{
Structural analysis of the northern Nagssugtoqidian orogen,West Greenland: an example of complex tectonic patterns in reworked high-grade metamorphic terrains
}

\author{
Stanislaw Mazur, Sandra Piazolo and G. Ian Alsop
}

Structural analysis of the deeply eroded northern flank of the Palaeoproterozoic Nagssugtogidian orogen shows marked regional variations in both the orientation and type of fabrics, as ischaracteristic of Precambrian high-gradeterrains subjected to polyphase deformation. $\mathrm{H}$ ere we investigate the relationship between strain, metamorphic grade, and the resulting structural patterns. The study area south of Aasiaat in W est G reenland consists of amphibolite- togranulite-gradeArchaean orthogneisses and relatively thin supracrustal units. The regional foliation displays aW SW -EN E to SW - N E strike associated with steep to moderate dips towards the W N W or SSE. Lineation trends are W SW -EN E and generally plunge gently towards the W SW. M esoscopic fold hinges are usually colinear with the regional lineation. A systematic change in the plunge of lineations occurs across the south-western part of the study area. Towards the south, the lineation plunge progressively increases, despite the generally uniform strike of foliation. This southward increase of lineation pitch is typically associated with thetransition from $L>S$ or $L=S$ shape fabrics in rocks characterised by a low pitch, to $S>L$ or $S$ fabrics in the zone of moderate to high pitch. The structural patterns point to subdivision of the study area into a southern domain mostly characterised by $S$ or $S>L$ shape fabrics and a moderate to high angle of lineation pitch, and a northern domain showing $\mathrm{L}>\mathrm{S}$ or $\mathrm{L}=\mathrm{S}$ fabrics and low angles of lineation pitch. This subdivision corresponds well with the map scale boundary between granulite facies rocks in the south and amphibolite facies rocks farther north. The observed structural pattern may be explained by two alternative tectonic models: (1) northward indentation of the previously cooled granulite block into the rheologically weaker amphibolite domain, and (2) strain partitioning within a mid-crustal transpression zone. In model 2 the northern domain represents a local ised zone dominated by strike-slip kinematics, whereas the southern domain shows evidence of mostly coaxial shortening. Recent geochronology supports the indentator model in spite of limited available data. D espite the details and structural complexities of the two tectonic models, the granulite and amphibolite facies domains seem to form autochthonous segments of a crustal section linked by a transitional zone that was only reactivated and reworked during indentation or transpression. The N agssugtoqidian compression was effectively transferred across this zone towards the northern amphibolite domain that suffered penetrative deformation during the Palaeoproterozoic event. The $\mathrm{N}-\mathrm{S}$ shortening was accommodated through folding, indentation and/or strike-slip displacements, rather than by thrusting and folding as seen south of the study area.

Keywords: deformation, GIS, Nagssugtogidian orogen, transpression, indentation tectonics, W est G reenland

\footnotetext{
S.M ., Institute of Geological Sciences, U niversity of Wroclaw, M axa Borna 9, 50-204 Wroclaw, Poland.

E-mail: smazur@ing.uni.wroc.pl

S.P., Geological Survey of D enmark and G reenland, $\varnothing$ ster Voldgade 10, D K-1350 Copenhagen K, D enmark. Present address: D epartment of G eology and Geochemistry, Stockholm University, 10691 Stockholm, Sw eden.

G.I.A., School of G eography and Geosciences, U niversity of St. Andrews, Fife KY16 9AL, U K.
} 


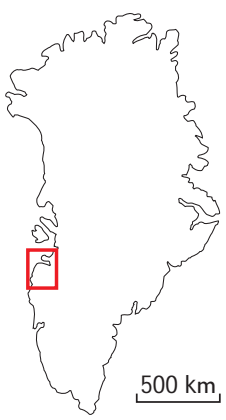

Q uaternary

$\square$ Surficial deposits

Palaeogene

$\square$ Basalt

$\mathrm{N}$ agssugtoqidian orogen

$\square$ Sisimiut charnockite

Arfersiorfik quartz diorite

Archaean orthogneiss, reworked

Amphibolite

Metasedimentary rocks

(mainly Archaean)

Metasedimentary rocks

(mainly Palaeoproterozoic)

Archaean craton

Granodioritic-granitic gneiss

O rthogneiss (unreworked)
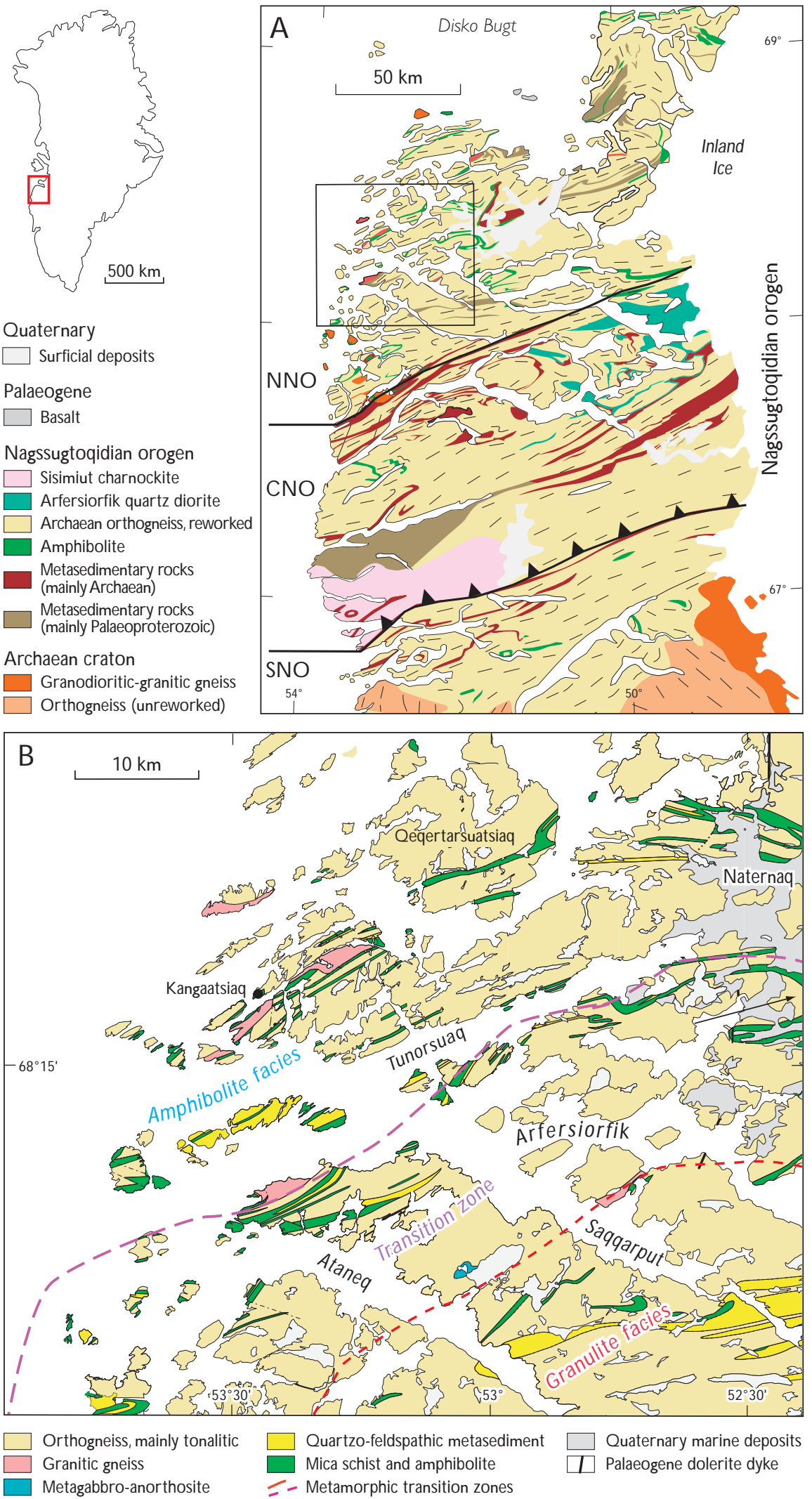

Fig. 1. A: Schematic geological map of the Nagssugtogidian orogen and adjacent foreland (modified from van Gool et al. 2002b). 0 utlined box shows location of the study area. SN $\mathbf{O}$, southern $\mathrm{N}$ agssugtogidian orogen; $\mathbf{C N} \mathbf{0}$, central $\mathrm{N}$ agssugtogidian orogen; $\mathbf{N} \mathbf{N} \mathbf{0}$, northern $\mathrm{N}$ agssugtogidian orogen. B: Simplified geological map of most of the study area (modified from van Gool et al. 2002a). 
Thedeeply eroded northern flank of thePal aeoproterozoic $N$ agssugtogidian orogen is exposed south of Aasiaat in central West Greenland (Fig. 1). These rocks bear record of tectono-thermal processes that operated at mid-crustal levels in a collisional setting and controlled the distribution of strain and metamorphic facies. The area shows a complex structural pattern that varies significantly from south to north. The aim of this work is to describe the regional variation of structural elements and to investigate the relationship between strain, metamorphic grade and the orientation of deformational structures. This then leads to the consideration of two different tectonic models, which have been developed to account for the observed structural pattern: (1) an indentor model proposed originally by Piazolo et al. (2004), and (2) a transpression zone model.

The study area covers the K angaatsiaq geological map sheet at scale 1:100 000 (Garde 2004), mapped in 20012002 by the $G$ eological Survey of D enmark and Greenland (GEU S; van Gool et al. 2002b). The directional and fabric type structural data sets were analysed using $\mathrm{G} \mathrm{eo-}$ graphic Information Systems (GIS) based techniques that proved to be a powerful tool in the investigation of complex structural patterns. Some of the structural data collected during this field campaign were presented by Piazolo et al. (2004) to illustrate the application of GIS in a multidisciplinary approach to survey high-grade terrains. 0 ur present study focuses on a more detailed analysis and interpretation of the structural relationships of the investigated area, a high-grade Precambrian terrain affected by more than one deformation phase, and whose interpretation is not unequivocal.

\section{Geological setting}

The study area covers over $3000 \mathrm{~km}^{2}$, and extends from $68^{\circ} \mathrm{N}-68^{\circ} 30^{\prime} \mathrm{N}$ and $52^{\circ} \mathrm{W}-53^{\circ} 15^{\prime} \mathrm{W}$, between the fjord of Ataneq in the south and the island of Q eqertarsuatsiaq in the north (Fig. 1). The area comprises the northern, $c$. $300 \mathrm{~km}$ wide exposure of the roughly $\mathrm{E}-\mathrm{W}$-trending $\mathrm{N}$ agssugtogidian orogen (Fig. 1). In the broadest sense, this tectonic belt resulted from a continent-continent collision between the Archaean N orth Atlantic Craton to the south and an Archaean continental mass to the north (e.g. Kal sbeek et al. 1987; C onnelly et al. 2000; van G ool et al. 2002a). The orogen is generally characterised by $E-W$ trending kilometre-scale folds and EN E-W SW-trending linear belts which overprint an Archaean fabric. $0 n$ the basis of the grade of metamorphic reworking, Ramberg (1949) and later M arker et al. (1995) distinguished south- ern, central and northern segments of the $\mathrm{N}$ agssugtogidian orogen (SN O, CNO and N N O respectively; Fig. 1). Detailed structural investigations within the $\mathrm{CN} O$ show that deformation in this area is dominated by thrust tectonics (M anatschal et al. 1998; van Gool et al. 1999).

Theinvestigated arealies within the N N $\mathrm{O}$ and is composed of amphibolite- to granulite-gradeArchaean orthogneissesinterlayered with relatively thin metasedimentary units (Fig. 1). This region is transected by major fjord systems that allow data collection al ong well-exposed coastal sections. Reconnaissancestudies (N oe-N ygaard \& Ramberg 1961; $H$ enderson 1969; $M$ arker et al. 1995; Kal sbeek \& N utman 1996; M engel et al. 1998; C onnelly et al. 2000) provided initial information on the structural style of the study area. A comprehensive description of the structural pattern was recently presented by Piazolo et al. (2004) and interpreted in terms of indentor tectonics with a rigid granulite-grade domain moving northwards into a rheologically weaker amphibolite facies domain.

Although quartzofeldspathic orthogneiss dominatesin the investigated area, the overall map pattern is governed bydiscontinuousN E-SW -trending supracrustal belts(Fig. 1). T hese 2-3 km thick sequences comprise several distinct lithological types: (a) monotonous, garnet-bearing quartzofeldspathic paragneiss local ly containing subordinate mafic volcanic and metapelitic intercalations; (b) pelitic to semipelitic schist with or without garnet and sillimanite, including thin quartzofeldspathic layers and rarely quartzite; and (c) layered maficto intermediatemetavolcanic successions with calc-silicate bands and/or pods.

Previous studies have demonstrated that the metamorphic grade of the N N 0 decreases northwards and is predominantly amphibolite facies, with granulitefacies rocks preserved only in the south-western corner of the study area near the boundary with the CN 0 (e.g. M arker et al. 1995). The contact between these two facies is transitional over a distance of 10-12 km and forms a zone nearly parallel to the strike of the regional foliation (Fig. 1). The granulitefacies gneisses aretypically pyroxene-bearing and enclose frequent melt pockets and cross-cutting veins. Thermobarometric analyses point to a peak temperature of $800 \pm 30^{\circ} \mathrm{C}$ at medium pressures of $6-7.5 \mathrm{kbar}$ (Piazolo et al. 2004). The amphibolite facies gneisses are lighter coloured and contain fewer biotite-bearing melt veins. They reveal peak metamorphism conditions of $650 \pm 30^{\circ} \mathrm{C}$ at 4-5 kbar (Piazolo et al. 2004). W ithin the supracrustal amphibolites, crystallisation of amphibole, usually developed along foliation planes, indicates a syntectonic fluid flux and associated metamorphism. No relics of earlier granulite facies assemblages are preserved in these rocks. Thrane\& Connelly (2006, this volume) carried out seve- 

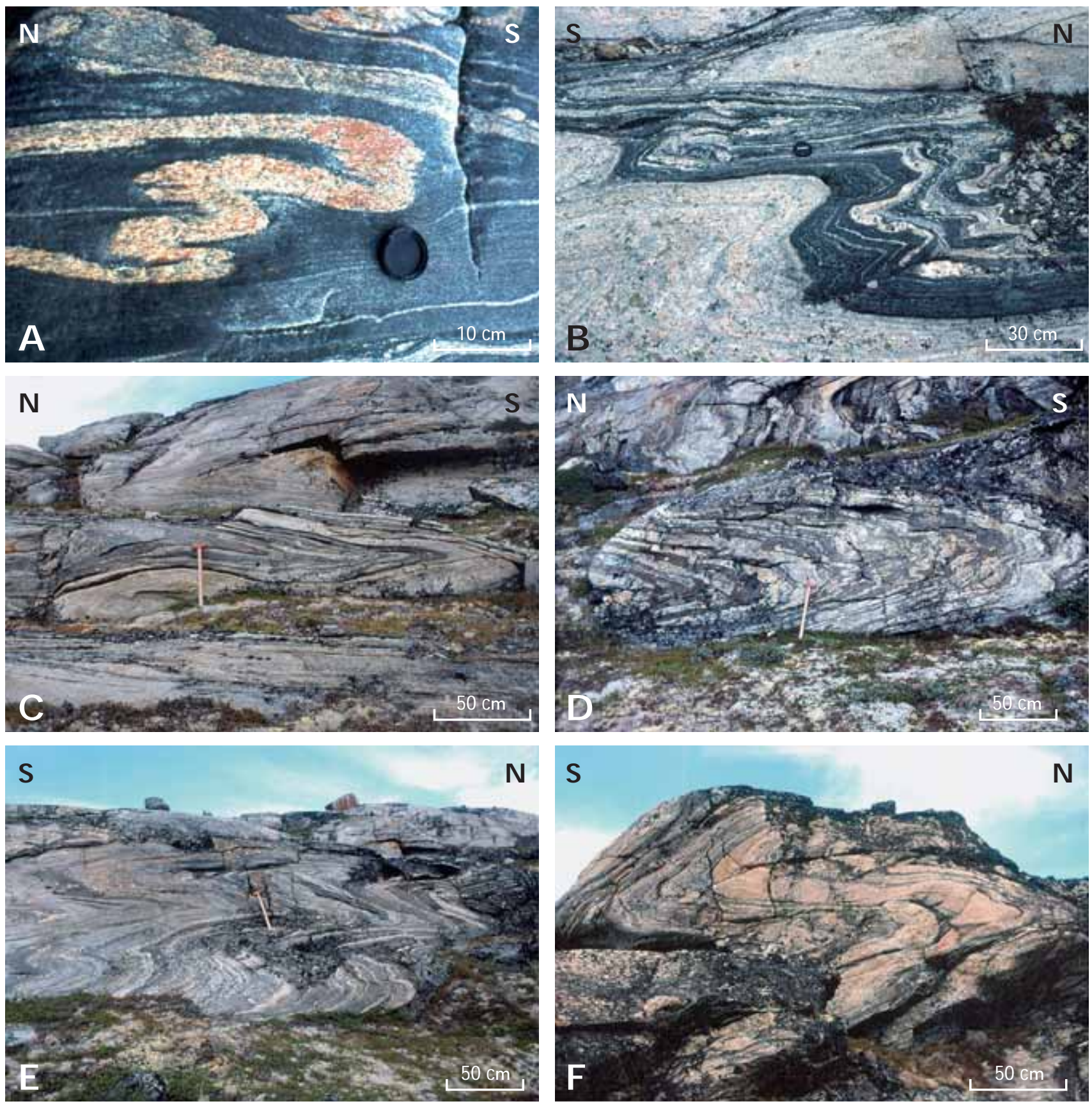

Fig. 2. Examples of mesoscopic folds in the orthogneisses and metasediments of the study area. $\mathbf{A}$ : $\mathbf{M}$ ain foliation $\mathrm{S}_{1}$ of orthogneiss developed parallel to the axial plane of isoclinal $F_{1}$ fold. B: Lithological boundaries and originally cross-cutting basic dykes folded by $F_{1}$ isoclinal fold and showing extensive migmatisation. $\mathbf{C}: \mathrm{S}_{1}$ foliation folded into isoclinal folds during the same progressive $\mathrm{D}_{1}$ event. $\mathbf{D}: \mathrm{S}_{1}$ foliation and its subsequent folding accompanied by pervasive migmatisation. $\mathbf{E}: \mathrm{S}_{1}$ foliation locally folded by $\mathrm{F}_{3}$ folds of variable geometry with fold axes developed subparallel to the lineation. $\mathbf{F}: S_{1}$ foliation of the orthogneiss folded by the $F_{3}$ fold with fold axes parallel to the lineation and $\mathbf{S}$-directed asymmetry. $\mathbf{N}$, north; $\mathbf{S}$, south. 
ral laser ablation and ion probe age determinations of zircon from within and adjacent to the present study area. $D$ eformation in the south-western part of the area is constrained by the emplacement age of $2748 \pm 19 \mathrm{M}$ a for a synkinematic granite which intrudes the orthogneiss. A Palaeoproterozoic deposition age of c. $1950 \mathrm{M}$ a was obtained from a metasediment within the $N$ aternaq supracrustal belt (Fig. 1), and broad rims of zircons from an Archaean sediment from Kangersuneq yiel ded a metamorphic age of c. $1850 \mathrm{M}$ a, suggesting that major $\mathrm{N}$ agssugtoqidian deformation and metamorphism occurred at around this time. Thrane \& Connelly (2006, this volume) also obtained an age of $1837 \pm 12 \mathrm{M}$ a for a vertical, straight pegmatite north-east of Kangaatsiaq trending $020^{\circ}$ and displaying sinistral shear along its margins, that is thought to date a late phase of overall N -S-directed Palaeoproterozoic shortening.

\section{Characteristics of directional structures}

The main foliation $\left(S_{1}\right)$ is axial planar to rare isoclinal $F_{1}$ folds that fold lithological boundaries as well as cross-cutting basic dykes (Fig. 2A). These dykes have been rotated into parallelism with the foliation on the fold limbs (Fig. $2 B$ ). The $S_{1}$ foliation was itself later folded into isoclinal folds, although this refolding may reflect the same progressive $D_{1}$ deformation event since no overprinting fabric is associated with it (Fig. 2C). A characteristic feature of these folds is the broad parallelism of their axial planes to the regional foliation $S_{1}$. $L_{1}$ mineral lineation is developed on thefoliation planes and is usually defined by a parallel alignment of amphibole crystals and/or elongated quartz-feldspar and biotite aggregates. The lineation is well developed in the amphibolite facies rocks but rather weak in the granulitefacies gneisses. In thetransition zone between theamphiboliteand granulitedomains (Fig. 1B), no mutually cross-cutting mineral lineations were detected and no evidence for fabric superimposition was observed. T he $L_{1}$ lineation is only rarely associated with kinematic indicators that are commonly symmetric and must have resulted from coaxial strain and/or a finitestrain combining the effects of several strain increments. Asymmetric fabrics have been observed only in zones of steeply dipping foliation, and typically indicate a sinistral rotational shear component in the present-day coordinates (Fig. 3). Restoration of the steep foliation attitude to more gentle regional dips would result in the same indicators implying a top-to-the-west or W SW sense of shear.

$T$ he $S_{1}$ foliation and its subsequent folding during the presumed progressive $D_{1}$ event, were accompanied by a
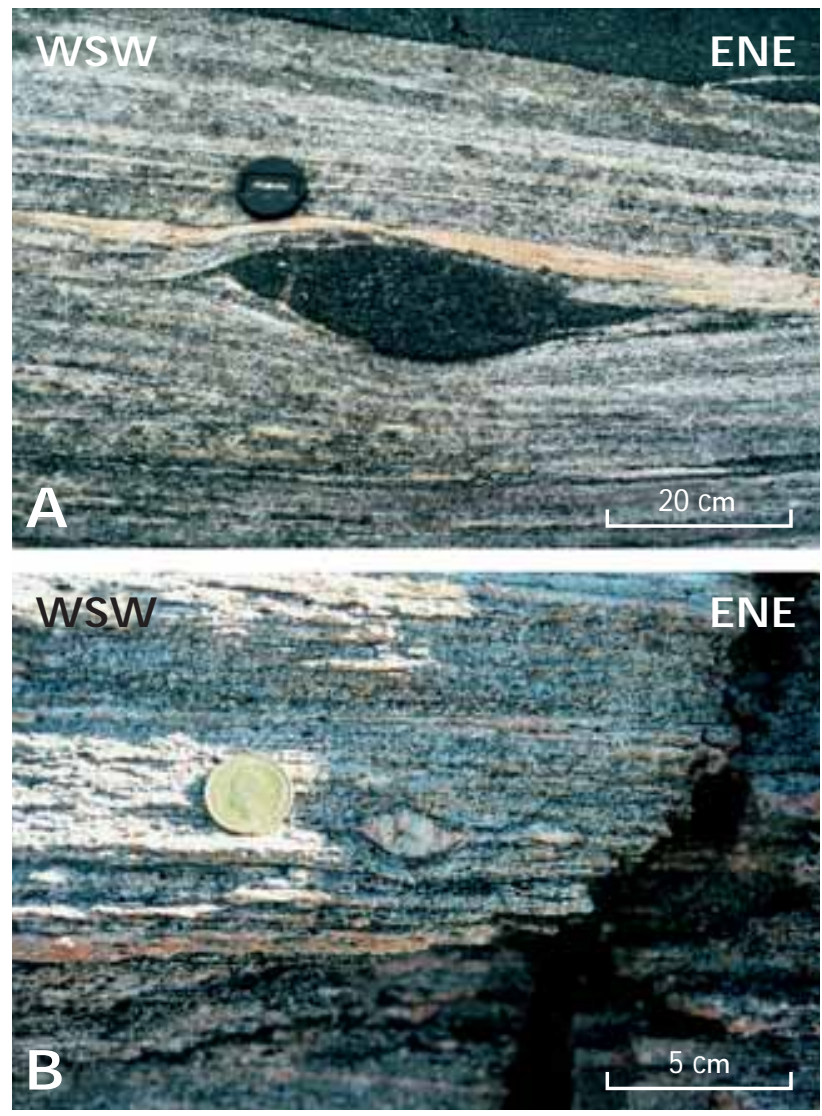

Fig. 3. Examples of sinistral (top-to-the W SW ) kinematic indicators in the orthogneisses of the study area. The lineation is plunging towards W SW on north-dipping foliation planes. A: Sheared, asymmetric amphibolite enclave. B: Sigmoidal K-feldspar porphyroclast.

long-lasting pervasivemigmatisation. Thisisdemonstrated by thecommon occurrence of migmatite layers or patches that are variably deformed and show mutually cross-cutting relationships. Some of them are parallel to the main foliation $S_{1}$ (Fig. 2D) whereas others define discordant veinsor dykes oblique to the regional fabric. Between these two end members are a range of cross-cutting veins that are deformed and reoriented to varying degrees. In the metasedimentary rocks of the $\mathrm{N}$ aternaq (Lersletten) area, the $S_{1}$ regional foliation is refolded by $F_{2}$ folds characterised by steep to subvertical fold hinges. These folds are developed at kilometre to centimetre-scale and, in a few cases, map scale $F_{2}$ folds can be seen refolding $F_{1}$ (A.A. $G$ arde $\&$ J.A. Hollis, personal communication 2003). $F_{2}$ folds are found exclusively within the metasedimentary belts and at their contacts with the adjacent gneisses. At a mesoscopic scale, they are represented by folds plunging steeply towards theSE and in few cases towards the north. A moderate to strong, SE-plunging mineral lineation is associated with the hinges of $F_{2}$ folds, locally deviating 




Fig. 4. Representation of foliation trends and dip directions in the study area. G B, granulite block; $\mathbf{T} \mathbf{Z}$, transition zone; $\mathbf{A B}$, amphibolite block.

from its regional trend although it remains the only lineation present. $A n S_{2}$ cleavage axial planar to $F_{2}$ is rarely, and only weakly, developed. Beyond $N$ aternaq, the $S_{1}$ foliation is refolded by $F_{3}$ folds of variable, often complex geometry with gently plunging fold axes developed subparallel to the $\mathrm{L}_{1}$ lineation (Fig. 2E). The frequency of such folds increases northwards within the amphibolitegrade rocks. Associated $F_{3}$ axial planes are locally marked by a subtle $\mathrm{S}_{3}$ cleavage, accentuated by local mica aggregates and discrete joints which cut the main $\mathrm{S}_{1}$ foliation. The distinction between $F_{2}$ and $F_{3}$ folds is primarily based on their different geometries since they both fold the regional fabric $\mathrm{S}_{1}$ and are not associated with penetrative axial cl eavages or intersection lineations. The hinges of $F_{2}$ folds are relatively steep and oblique to the regional lineation, whereas $\mathrm{F}_{3}$ axes are gently inclined and run parallel to the lineation $\mathrm{L}_{1}$. The $\mathrm{F}_{3}$ mesoscopic folds are frequently asymmetric with fairly uniform SSE vergence in the area south and west of Kangaatsiaq (Fig. 2F).

\section{Orientation of directional structures}

On the map scale, the regional foliation displaysa W SW EN E to SW -N E strike associated with steep to moderate dips towards the N N W or SSE (Fig. 4). Shallow-dipping foliations $\left(<30^{\circ}\right)$ are rare and randomly distributed throughout the study area. Their variable directions suggest that they are associated with the hinge zones of $F_{3}$ folds developed at different scales (Fig. 4). M oderately and steeply dipping foliations show a distinctly discretegrouping within the investigated area. The former predominate in the south-eastern corner of the area, corresponding with the granulite-grade block, whereas the steeply dipping foliations are developed in its central part, forming a wide belt along Tunorsuaq (Fig. 4). This belt coincides with a transition zone between the granulite and amphibolite facies domains and partly with the south-eastern margin of the latter (see Figs 1, 4). T he strike of foliation dipping steeper than $30^{\circ}$ remains fairly consistent throughout the area, while the dip direction varies only in the case of sub- 
Fig. 5. Attitudes of foliation $S_{1}$ and stretching lineation $L_{1}$ in the northern amphibolite facies block (A, C), and southern granulite facies block (B, D). The positions of the poles to the foliation girdles and maximum of lineation measurements are indicated in stereoplots A, B and C, D, respectively.
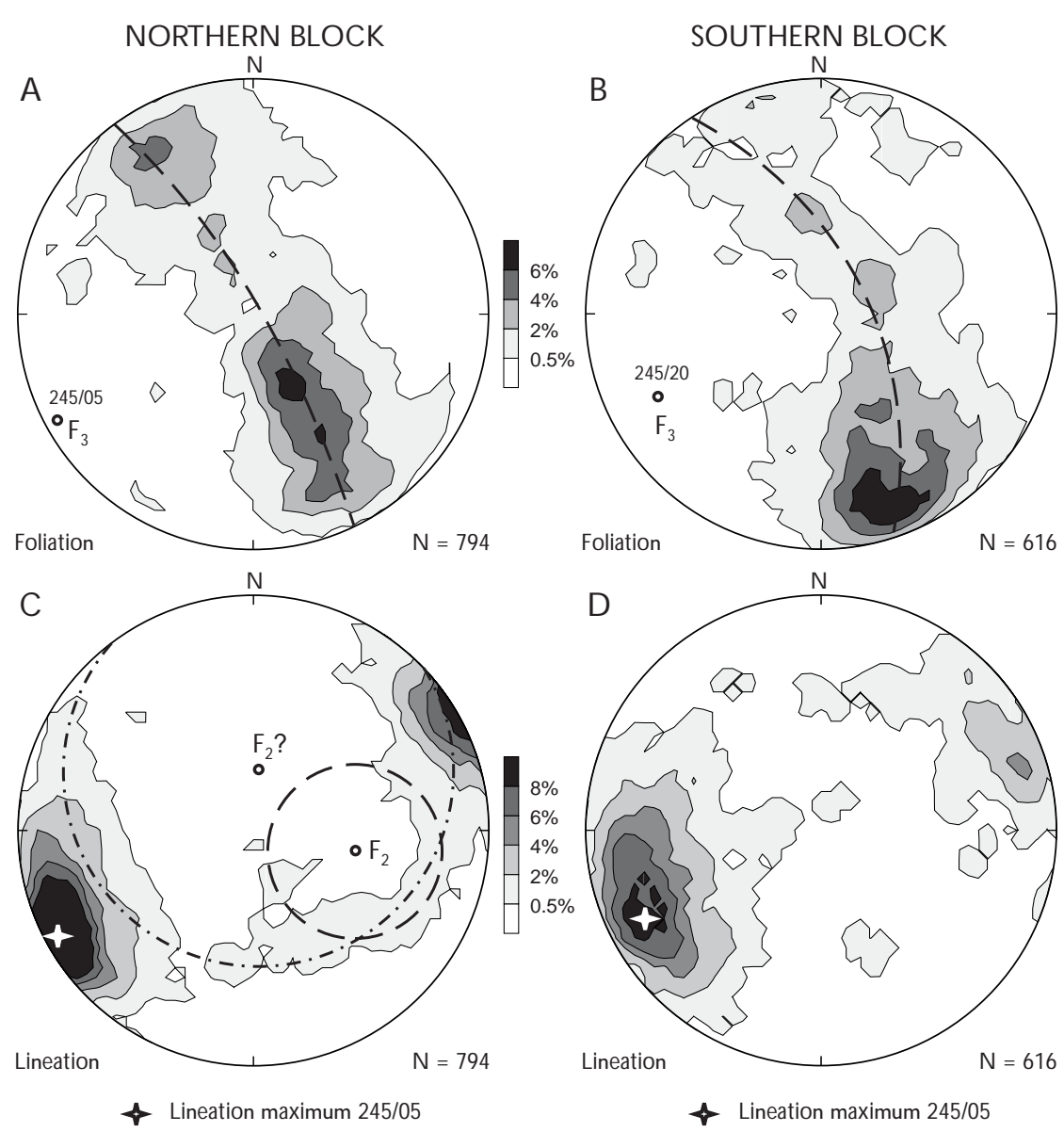

vertical planes $\left(>60^{\circ}\right)$. O n stereoplots, the poles to foliation are scattered along a regular girdle produced by the $\mathrm{F}_{3}$ folds (Fig. 5).

In the southern granulite facies block the vast majority of foliation measurements cluster in one maximum, suggesting that late folding is insignificant or absent in this area (Fig. 5). This maximum corresponds to the foliation dipping moderately to steeply towards the N N W, while the axis of the foliation girdle plunges gently to theW SW at $20^{\circ}$. In the northern, amphibolite facies block measurements are more evenly distributed along the foliation girdle, providing evidence for the regional importance of $\mathrm{F}_{3}$ folding (Fig. 5). In contrast to the southern block, the stereographic girdle axisisalmost subhorizontal. Although the foliation patterns in the southern and northern blocks are fairly similar, a striking difference occurs within the latter between the rheologically competent orthogneisses and relatively incompetent supracrustal formations (Fig. 6). The orthogneisses reveal a regular girdle perfectly controlled by a cylindrical geometry of the $\mathrm{F}_{3}$ folds. In contrast, the less competent supracrustal rocks display a pronounced foliation scatter, reflecting a complex interfer- ence between the effects of the (possibly noncylindrical) $\mathrm{F}_{2}$ and $\mathrm{F}_{3}$ folding.

The lineation trends W SW -EN E over the whole study area, and frequently plunges gently towards theW SW (Fig. 7). Shallow lineations $\left(<15^{\circ}\right)$ are concentrated in the northern and central parts of the investigated area (Fig. 7), and commonly coincide with the subvertical foliation within theamphibolite facies block and theassociated transition zone towards the granulite facies block. Conversely, lineations plunging steeper than $15^{\circ}$ group largely in the south-eastern corner of the area, corresponding with the granulite block, and show mostly W SW-directed plunges. M esoscopic $F_{3}$ fold hinges are usually colinear with the regional lineation, and this is also the case at the larger scale since the lineation maxima are located near the pole of the foliation girdle on stereoplots (cf. Fig. 5). In the amphibolite facies block, the lineation is shallow and relatively well grouped in the maximum representing the subhorizontal WSW-ENE trend. A significant scatter occurs only in the $\mathrm{N}$ aternaq area, which is displayed on the map by relatively steeply plunging lineations (Fig. 7) and on stereoplots by data distribution along a small cir- 

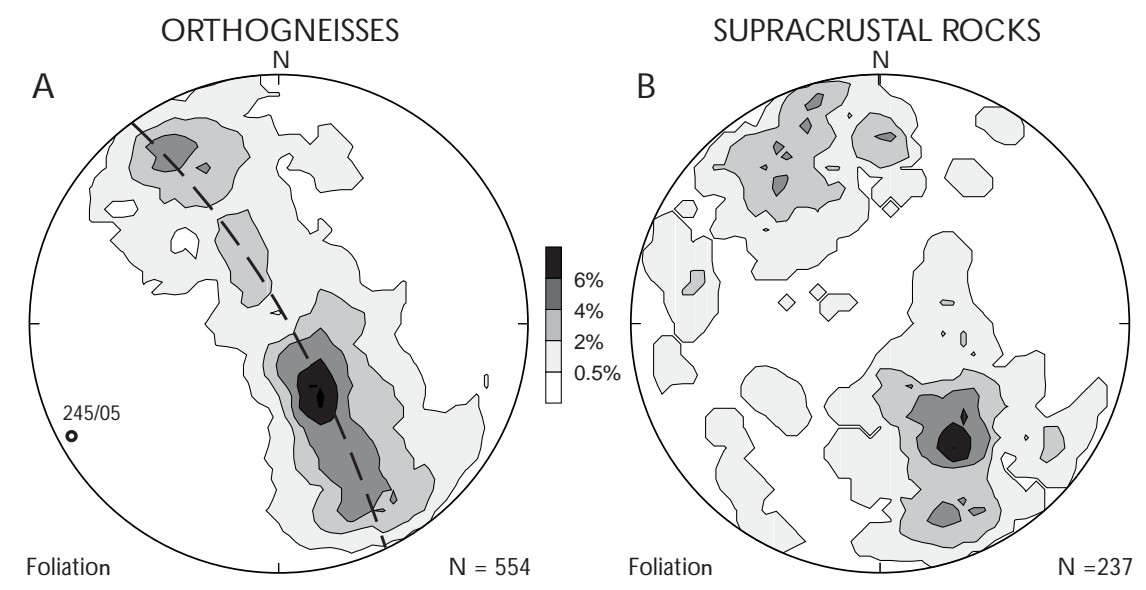

Fig. 6. Attitudes of foliation $\left(S_{1}\right)$ and stretching lineation $\left(L_{1}\right)$ in the orthogneisses $(\mathbf{A}, \mathbf{C})$ and supracrustal rocks (B, D ) of the northern amphibolite facies block. The position of the pole to the foliation girdle and maximum of lineation measurements are indicated in stereoplots A and C, D, respectively.
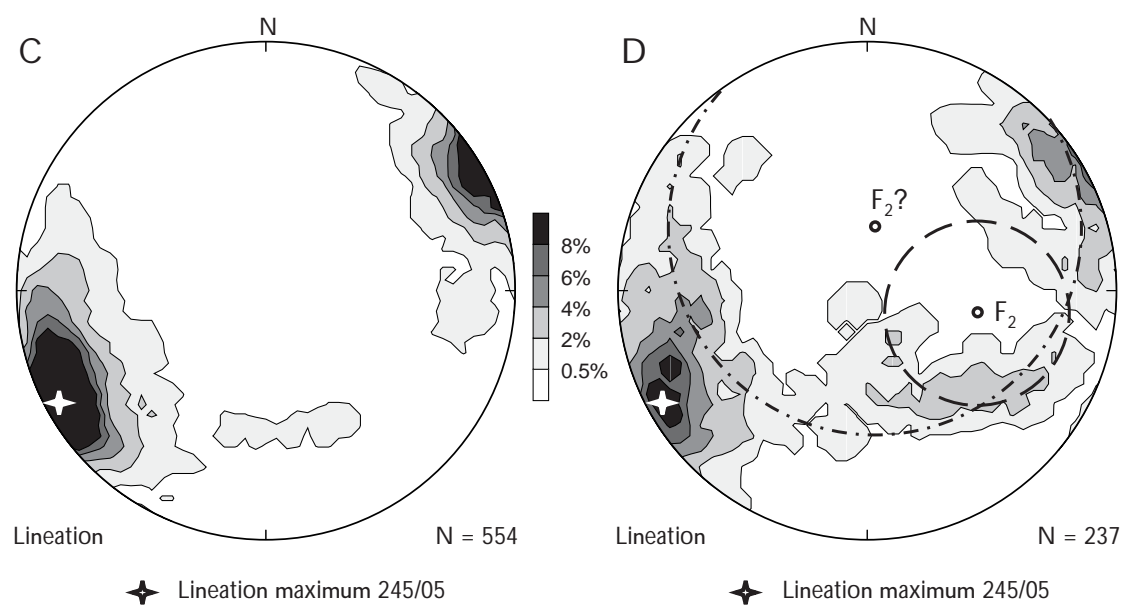

cle (Fig. 5). A dispersal of lineation measurements is produced in that area by steeply plunging $F_{2}$ fold hinges whose orientation corresponds to the centre of a small circle defined by the scatter of the lineation (Fig. 5). Two different small circles can be delineated on the stereoplot (Fig. 5) based on the lineation scatter. 0 ne is centred at the orientation of $F_{2}$ hinges steeply inclined to the SE that are relatively frequent as mesoscopic structures. The second is developed around the nearly vertical north-plunging $F_{2}$ hinges rarely found in the outcrops but probably important at the map scale. The lineation scatter induced by the $F$ folding is very clear in the supracrustal rocks, where as it is almost absent in the orthogneisses (Fig. 6). This relationship is consistent with the field observation that the $\mathrm{F}_{2}$ folds are developed al most exclusively in the metasediments. In the southern block the lineation is slightly steeper than in the north and shows a mean plunge of $c$. $20^{\circ}$. Its maximum is more diffuse than in the amphibolite-gradeblock and more lineations are rel ativel y steep (> $15^{\circ}$ ). N evertheless, the average lineation trend defined by the position of maxima on stereoplots is exactly the same for the amphibolite and granulite facies domains (Fig. 5).

In order to better understand the geometric relation- ships between planar and linear fabric elements during deformation, they may be directly compared on fabric topology plots in terms of fabric trends and lineation pitch (see Alsop \& H oldsworth 2004 for a review). The angle of pitch may be defined as the angle that a line makes with the strike of a surface, when measured within that plane (Fig. 8A). A significant variation in the angle of lineation pitch on the regional foliation surface is observed (Fig. 8B); this may becaused by two independent factors: (1) variable plunge of the lineation, and (2) variable dip direction of the foliation. The latter feature seems to be a consequence of local folding, since a high pitch angle (> $45^{\circ}$ ) is most characteristic for SW -dipping foliations (Fig. 9) that represent the hinges of $F_{3}$ folds (Fig. 5). On the other hand, a majority of measurements correspond to foliation dipping to the N W or SE that reveals a low or moderate pitch angle (Fig. 9). Such a foliation pattern is consistent with the regional attitude of foliation inclined towards the N W and only locally reoriented on limbs of the $F_{3}$ folds. Since the $F_{3}$ folds are only of minor significance in the southern part of the study area characterised by higher pitch values (Fig. 8), and the majority of lineations were measured on steep to subvertical foliation sur- 


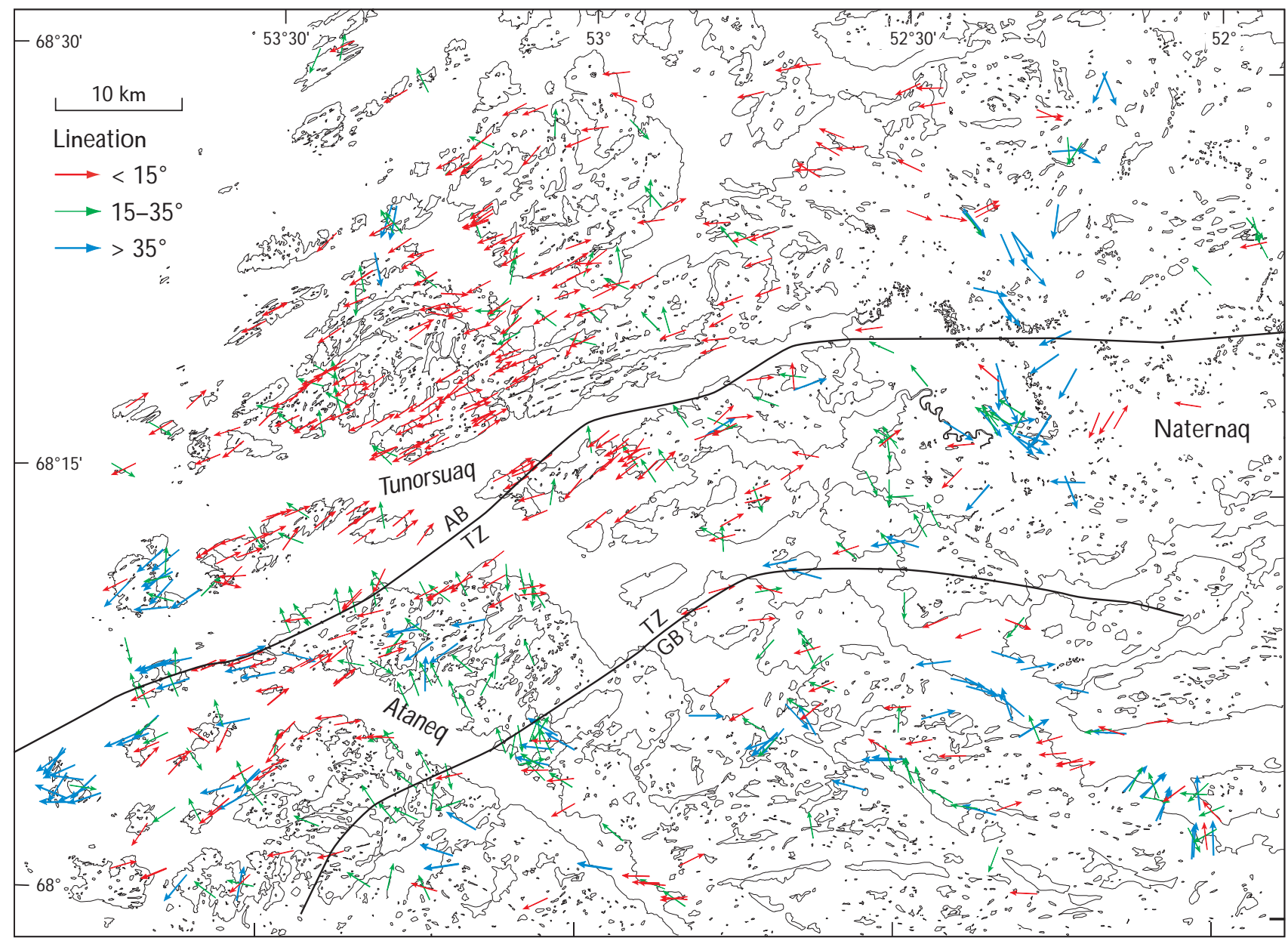

Fig. 7. Representation of lineation trends and plunge directions of the study area. G B, granulite block; $\mathbf{T} \mathbf{Z}$, transition zone; $\mathbf{A B}$, amphibolite block.

faces, the broad scatter of the pitch angles can be attributed to variations in the lineation plunge (Fig. 10). 0 nly a minority of measurements plot away from the line that indicates the similarity of pitch and plunge angles (Fig. 10). Thus, the change of foliation strike plays a less important role in the distribution of pitch angles. The low pitch angle $\left(<15^{\circ}\right)$ is characteristic of the central and northern parts of the study area (Fig. 8), corresponding to the amphibolite facies block and the transition zone to thegranulite facies block. This is the area that is additionally characterised by the steep foliations and shallow lineation plunge. The higher pitch angles (exceeding $15^{\circ}$ ) are more common in the south-east corner of the study area within the granulitefacies gneisses, wherethey are related to relatively steep lineations occurring on the moderately to steeply inclined foliation.

A systematic change in the plunge of lineations can be observed across the south-western part of the study area (Fig. 7). The steep SW - N E-striking foliation around Tunorsuaq is associated with the gently plunging lineation that defines a low angle of pitch on the foliation. Towards the south, however, the plunge of lineation becomes progressively steeper despite the generally uniform strike of foliation (Fig. 4). A pitch versus lineation trend diagram (Fig. 11) demonstrates that the increase in pitch is unrelated to the change of lineation trend. This means that lineations are typically not reoriented on fold limbs, and that folds, if present, are mostly colinear with lineation. Furthermore, in the north-western part of the area the lineations plunge gently to the SW and NE to define a series of culminations and depressions, that are clearly illustrated by the opposing plunges on the south side of Tunorsuaq and the outer islands to the west-south-west (Fig. 7). This sinuosity of lineations and associated fold hinges defines a large scale whaleback pattern consistent with a dominantly subhorizontal and approximately $\mathrm{N}-\mathrm{S}$ contractional strain (cf. Piazolo et al. 2004).

Thefiniteplanar (S) and linear (L) shape fabricswithin a high-strain rock may be qualitatively described (Flinn 1978). Consequently, the relative dominance of these re- 

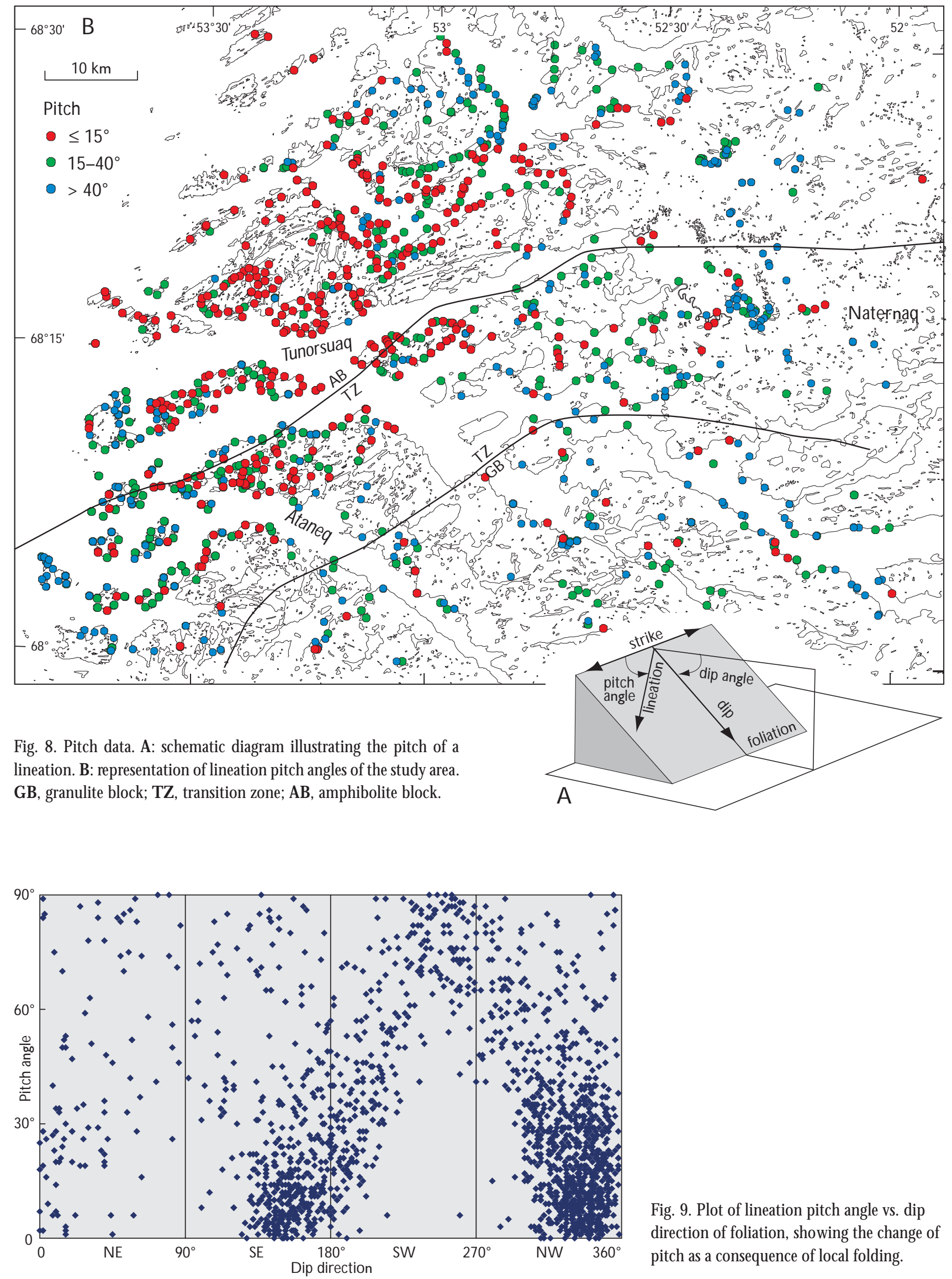

Fig. 9. Plot of lineation pitch angle vs. dip direction of foliation, showing the change of pitch as a consequence of local folding. 
Fig. 10. Plot of lineation pitch angle vs. lineation plunge, showing the contribution of changing lineation plunge to the total variation of pitch. M easurements located on the straight line connecting the lower left and upper right corners of the plot have been taken on vertical foliation planes.

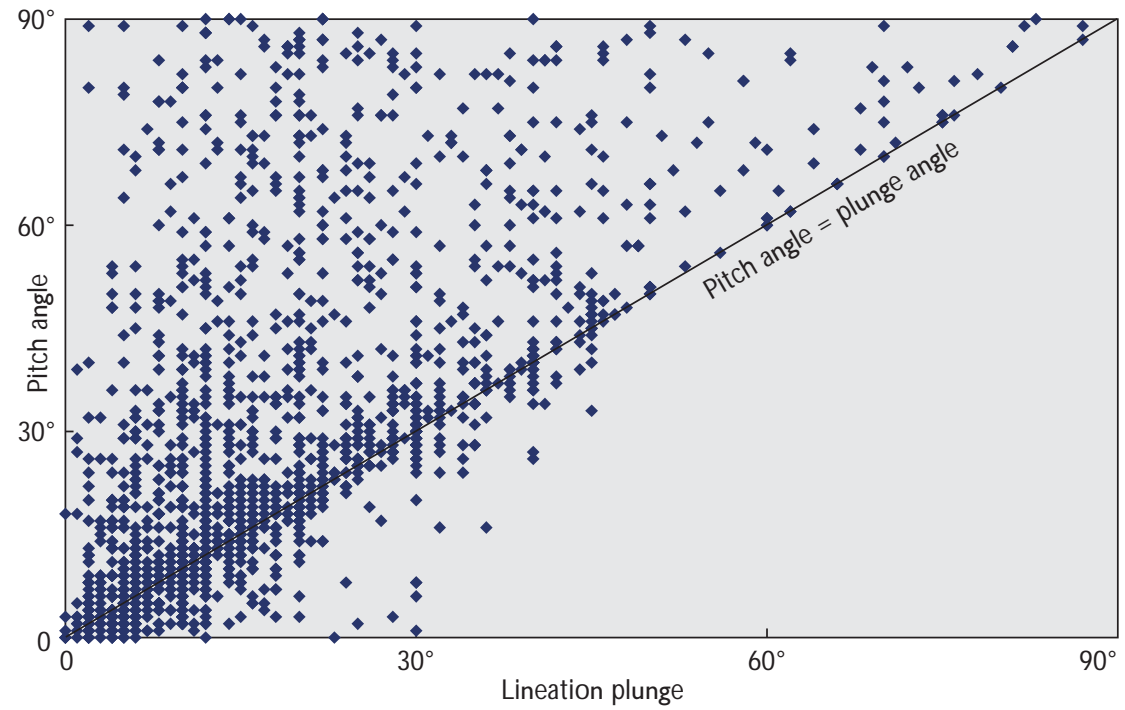

spective components enables a distinction to be made between fabrics that are foliation dominated (S tectonite), lineation dominated ( $L$ tectonite) or contain a combination of foliation and lineation (SL tectonite). The pattern shown by the spatial distribution of fabric types in the study area is clearly differentiated. Thenorth-western part of the area is dominated by $L S$ and $L>S$ fabric types whereas the south-eastern part reveals a vast preponderance of S or S > L types (Fig. 12). The southward increase of lineation pitch is typically associated with the transition from $L>S$ or $L S$ shape fabrics in rocks characterised by a low pitch, to $S>L$ or $S$ fabrics in the zone of moderate to high pitch. Constrictional fabrics, i.e. $L$ and $L>S$ fabrics, aretypical of rocks with shallowly plunging lineations on the steep foliation belonging to the amphibolite facies block and the transition zone to the granulite facies block. The latter is dominated by the flattening fabric types, i.e. $S$ and $S>L$ fabrics, which arecommon in rocks containing steeply plunging lineations.

\section{Discussion}

Threemain observations can bemadeconcerning the data presented above: (1) structural elements, i.e. lineations, foliations, folding and fabric type, vary with lithology, (2) two broad domains with different structural patterns can bedistinguished, and (3) thestructural stylein theN N 0 is markedly different to that previously described from the CN O , e.g. by M anatschal et al. (1998) and van G ool et al. (1999).

The observed scarcity of mineral lineations in the gran-
Fig. 11. Plot of lineation pitch angle vs. lineation trend, showing the variation of pitch despite the uniform trend of lineation.

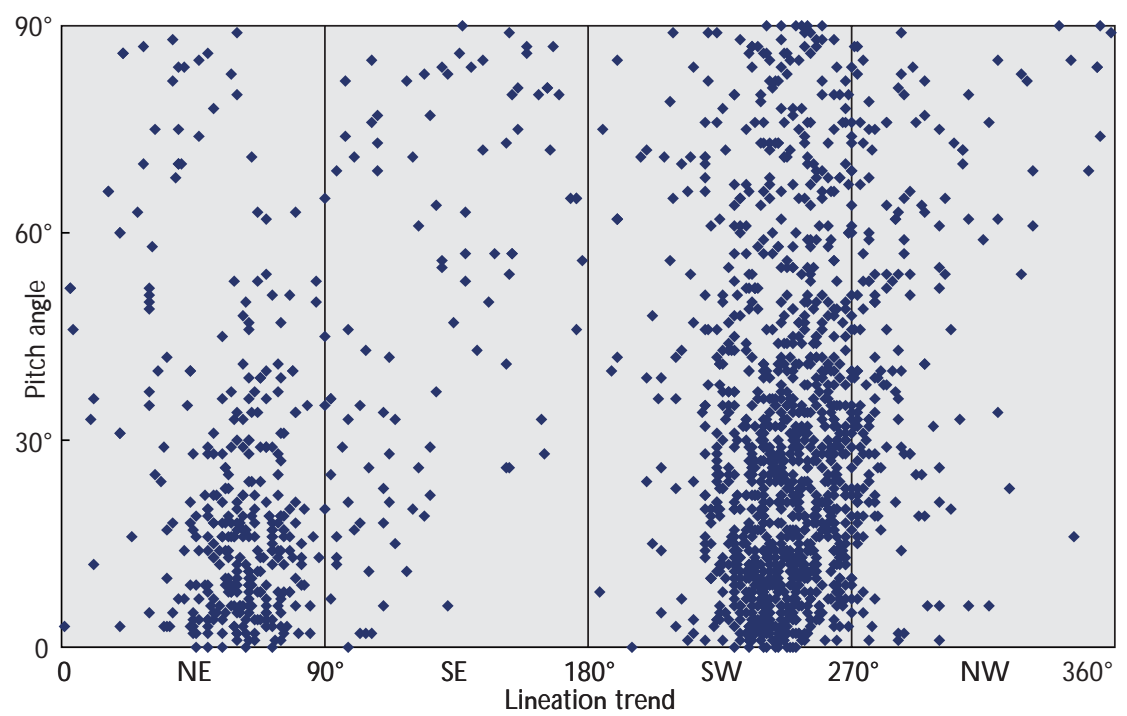




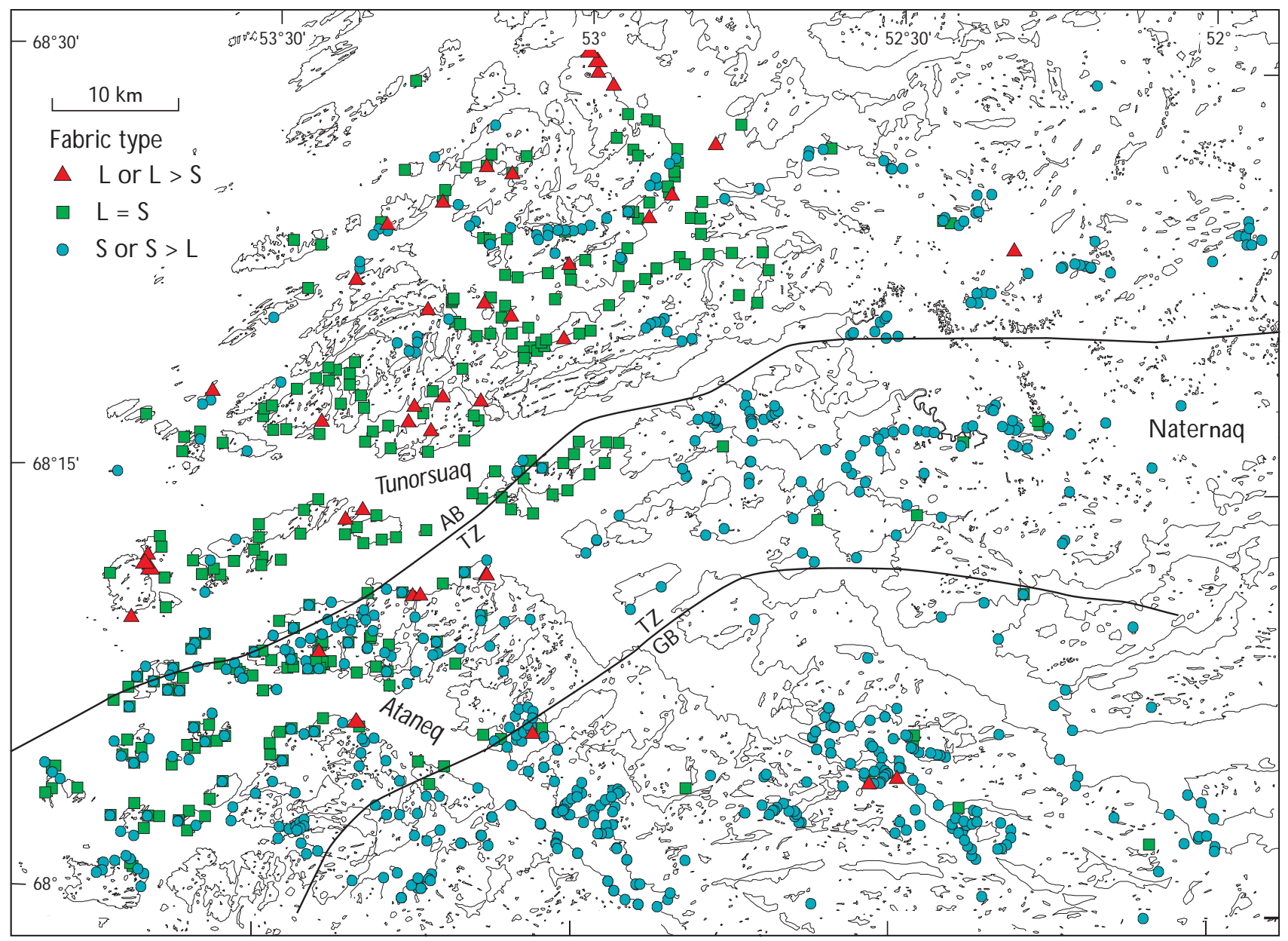

Fig. 12. Spatial distribution of fabric types (terminology af Flinn 1978). GB, granulite block; TZ, transition zone; AB, amphibolite block.

ulite facies gneisses could be attributed to the absence of minerals with a high shape aspect ratio. If such minerals are lacking, lineations of thetype that forms by rigid rotation or due to growth parallel to the maximum extension direction or transport direction can hardly develop. N evertheless, aggregate lineations that form by dynamic recrystallisation and material transfer should be expected in the granulite facies gneisses. Since even these lineations are lacking in the southern block, it seems that the scarcity of linear structures in this area is not only a function of lithology but also reflects specific features of deformation history. In the northern block, a significant strain partitioning between orthogneisses and supracrustal formations is indicated by the effects of $\mathrm{F}_{2}$ folding in metasedimentary rocks and the resultant scatter of foliation and lineations in these rocks (Fig. 6). T his points to the concentration of deformation in rheologically weak metasedimentary belts that accommodate the bulk of strain induced during $F_{2}$ folding. The competent orthogneisses experienced only subsequent $F_{3}$ folding, when they were de- formed together with associated less competent supracrustal rocks.

At the western limb of the $\mathrm{N}$ aternaq supracrustal belt, there is a structural discordance with another $\mathrm{E}-\mathrm{W}$-trending supracrustal unit farther to the west. This structural discordance may suggest the presence of some kind of 'stockwerke tectonics' (Wegmann 1935), in addition to the inferred strain partitioning between the orthogneisses and metasedimentary rocks. The application of the 'stockwerke' model to the $\mathrm{N}$ aternaq belt itself remains an intriguing problem that cannot be resolved at present, due to the lack of sufficient information on the time relationship between the structural discordance and the main phase(s) of folding and metamorphism.

Disregarding the local complexity at $\mathrm{N}$ aternaq, thegeneral structural pattern described in this paper allows subdivision of the study area into two main domains: (1) a southern domain mostly characterised by $S$ or $S>L$ shape fabrics and a moderate to high angle of pitch, and (2) a northern domain showing $L>S$ or $L S$ fabrics and low 
angles of lineation pitch. This subdivision compares well with the map scale variation of the metamorphic grade from granulite facies in the south to amphibolite facies further north. The contact between these two facies istransitional and forms a gently curved boundary that is subparallel to the strike of the regional foliation (Piazolo et al. 2004). This division of the study area into two contrasting blocks, indicated by the structural data and variation of metamorphic grade, can be explained by two models, namely (1) an indentor model, and (2) a transpressive deformation model, the relevance of which is briefly discussed below.

Theindentor model, originally developed by Piazolo et al. (2004), invokes a twofold deformation history. D uring the first event the southern block was subjected to a coaxial flattening under granulite facies conditions (Fig. 13B - time A). A fairly uniform strain developed at that time and is manifested by prevailing $S$ or $S>L$ shape fabrics. During the second event (Fig. 13B - time B) the previously cooled granulite grade block acted as an indentor, with the amphibolite facies domain being plastered and moulded around the rigid block. The structural pattern and mineral assemblages of the southern domain were only modified in a transition zone that experienced retrogression to the amphibolite facies. At the same time, the amphibolite grade northern domain was subjected to mostly coaxial strain, including an important constrictional component. The resultant structural grain in the amphibolite facies rocks mimics the geometry shown by the boundaries of the southern block.

The alternativemodel (Fig. 13C) explains the observed structural relationshipsin terms of strain partitioning within a transpression zone (for a review of transpression see $\mathrm{H}$ oldsworth et al. 2002, and references therein). In this model, the different structural patterns documented in the northern and southern domains were produced during a single deformation event. Consequently, the model implies a continuity of the structural grain across the transitional zone as well as a gradual change in the orientation of directional structures, fabric type and kinematics of strain. T he southern domain was mostly subjected to coaxial flattening, resulting in $S$ or $S>L$ shape fabrics with a moderately plunging lineation. $T$ henorthern domain was deformed in a wrench-dominated regime, characterised by a constrictional or plane strain with a significant rotational strike-slip component. H ence, the northern block reveals $L>S$ and $L S$ shape fabrics and shallowly plunging lineations. A sinistral sense of displacement assumed in themodel isconsistent with rareobservations in the field of kinematic indicators with the appropriate asymmetry.

The indentor model explains the arcuate swing of the structural grain around the granulitefaciesblock, the map scale geometry of which may appear to control the foliation and lineation patterns within the amphibolite facies block further north. A serious weakness of the indentor model is the lack of evidence for fabric overprinting in the boundary zone between the two domains despite the assumed twofold deformation. H owever, high strain in thetransitional zone could account for the obliteration of interference patterns and the apparent continuity of structural grain. The transpression zone model accounts for the presence of steep $\left(\mathrm{F}_{2}\right)$ fold hinges in the Naternaq supracrustal belt that are expected to develop within the wrenchdominated part of the transpressive system. The model also explains the contrast of structural style between the northern and southern domain without a detectable tectonic boundary or an overlap of structural patterns. C onsequently, it is consistent with an apparent continuous transition linking the structural patterns within the granulite and amphibolite blocks. The somewhat steeper plunge of lineations within the granulite facies domain may indicate a greater component of coaxial strain in that area. H owever, the potential strain partitioning, as revealed by the lineation pattern, is relatively weak for a transpression zone. The partitioning of strain that takes place between the orthogneisses and supracrustal rocks within the northern amphibolite facies block is consistent with both of the discussed models. In addition, both models are consistent with a dominantly subhorizontal and approximately $\mathrm{N}$-S contractional strain in thenorthern block causing the small-scale porpoising and large-scale whalebacking of lineations and associated fold hinges.

Thus, even a detailed structural analysis does not allow us to determine unequivocally which of the two models is the more appropriate. N evertheless, the presented structural models can be indirectly verified by geochronological data, which constrain the age of peak metamorphism and associated deformation in the northern amphibolite facies block as Palaeoproterozoic (Thrane \& Connelly 2006 , this volume). Furthermore, the late Archaean crystallisation age of syndeformational granites emplaced at Saqqarput (Fig. 1) and at the southern margin of the N N 0 (C onnelly \& M engel 2000; Thrane \& Connelly op. cit.), points to a lack of significant deformation in the southern block from the late Archaean onwards. This is in conflict with the coincidence of deformation between the northern and southern blocks required by the transpression model and, thus, supports the indentor model. This is corroborated by the occurrence of undeformed but metamorphosed mafic dykesof likely Palaeoproterozoicorigin emplaced at the southern margin of the investigated area (Glassley \& Sørensen 1980; Árting 2004). 


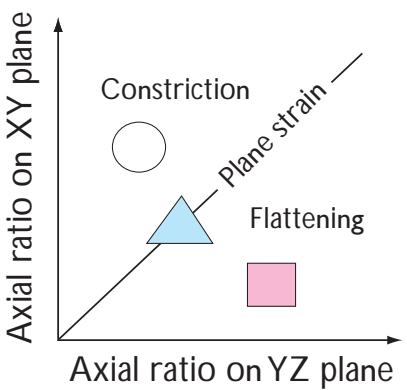

Model I (Piazolo et al. 2004). O bserved fabrics developed during two deformational events Time $A$, at granulite facies conditions
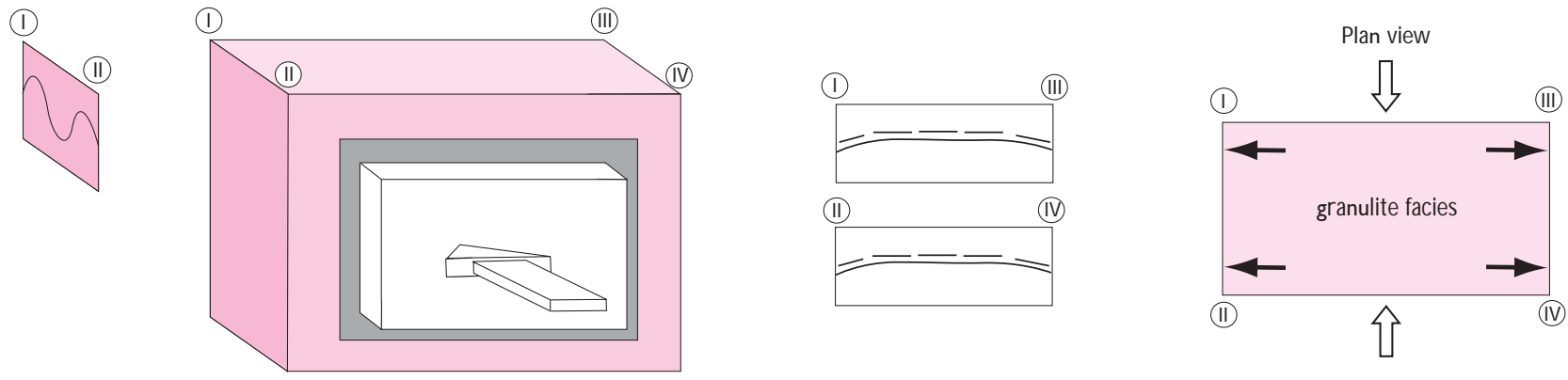

Time $B$, at amphibolite facies conditions
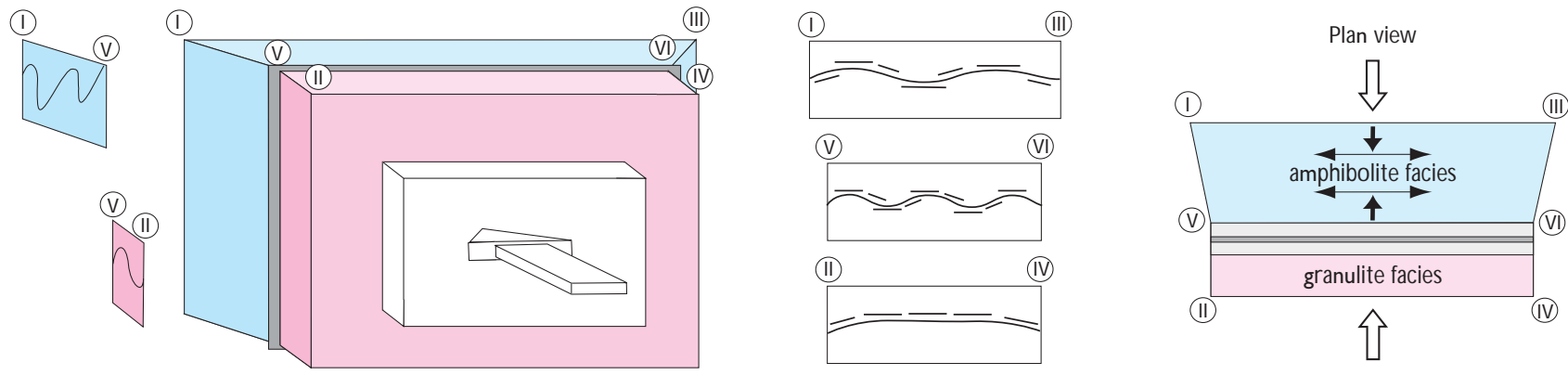

Model II (discussed in this paper). Fabrics developed during a single transpressional event
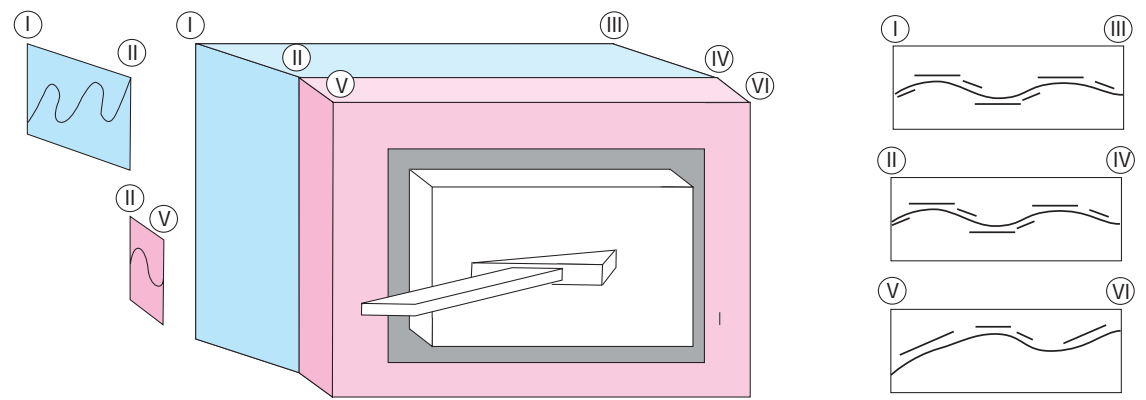

Fig. 13. Schematic indentor and transpression zone models with expected fabric types and fold patterns. A: Flinn graph with schematic qualitative descriptions of the finite planar (S) and linear ( $\mathbf{L}$ ) shape fabrics. B: Indentor model. C: Transpression zone model. 
The $\mathrm{F}_{3}$ folding apparently postdates the juxtaposition of the granulite and amphibolite blocks and had a relatively minor influence on their contact zone. The northward increase in intensity of $F_{3}$ folding is readily explained by the rheological weakness of the amphibolite facies domain during cooling. The origin of $\mathrm{F}_{3}$ folds provides evidence for prolonged, approximately $\mathrm{N}$-S-directed compression, the age of which is roughly constrained by the previously mentioned $1837 \pm 12 \mathrm{M}$ a pegmatite (T hrane $\&$ Connelly 2006 , this volume).

O ur structural data al so show that compressional stress related to the growth of the $\mathrm{N}$ agssugtogidian orogen was effectively transferred across the lower crust, and that the amphibolite facies domain south of Aasiaat was subjected to the pen etrative Palaeoproterozoic deformation. Therefore, this area represents an integral part of the N agssugtoqidian orogen despite the obvious paucity of Pal aeoproterozoic crustal components. In contrast to the southern part of the orogen, the overall $\mathrm{N}-\mathrm{S}$ shortening induced by the $\mathrm{N}$ agssugtogidian collision was accommodated in the study area through indentation and folding, in contrast to the central part of the orogen that displays significant thrust tectonics.

\section{Concluding remarks}

The indentor and transpression-driven tectonic models discussed in this paper share a number of features which shed a new light on the evolution of the northernmost $\mathrm{N}$ agssugtogidian orogen. The granulite and amphibolite facies blocks distinguished in the study area appear to be (par)autochthonous, and their boundary is only reactivated and reworked during indentation or transpression.

The area studied shows excellent examples of Precambrian deformation thatarecharacterised bysignificantstrain partitioning into less competent metasedimentary rocks. The presence or absence of lineations may be influenced significantly by lithology and metamorphic grade. Complex structural patternsmay not al ways conclusively reveal thestructural history on their own, hence geochronological data are essential in distinguishing between different deformation models such as transpression or indentation. In addition, it is apparent that the tectonic styles of the lower to middle crust can be highly variable within the same orogen. D eformation may vary from thrust-dominated in the central portion to folding associated with indentation or transpression on its flanks.

\section{Acknowledgements}

C ritical reviews by C.R.L. Friend and an anonymous re viewer as well as constructive comments by A.A. Garde helped us to improve the manuscript, and are gratefully acknowledged. Structural information acquired from other members of the GEU S field parties in 2001-2002 significantly contributed to the data base used in this paper.

\section{References}

Alsop, G .I. \& H oldsworth, R.E. 2004: The geometry and topology of natural sheath folds: a new tool for structural analysis. Journal of Structural G eology 26, 1561-1589.

Árting, U E. 2004: A petrological study of basic dykes and sills of assumed Palaeoproterozoic agein central western G reenland, 122 pp., two appendices. U npublished M .Sc. thesis, University of C openhagen, Denmark.

Connelly, J.N . \& M engel, F.C. 2000: Evolution of Archean componentsin the Pal eoproterozoic $N$ agssugtogidian orogen, West $G$ reenland. Geological Society of America Bulletin 112, 747-763.

Connelly, J.N ., van G ool, J.A.M . \& M engel, F.C. 2000: Temporal evolution of a deeply eroded orogen: the N agssugtogidian orogen, W est Greenland. Canadian J ournal of Earth Sciences 37, 1121-1142.

Flinn, D. 1978: Construction and computation of three-dimensional progressive deformations. Journal of the G eological Society (London) 135, 291-305.

Garde, A.A. 2004: Geological map of G reenland, 1:100 000, Kangaatsiaq 68 V.1 Syd. Copenhagen: Geological Survey of Denmark and $\mathrm{G}$ reenland.

Glassley, W.E. \& Sørensen, K. 1980: Constant PsT amphibolite to granulite facies transition in Agto (West G reenland) metadolerites: implications and applications. Journal of Petrology 21, 69-105.

$\mathrm{H}$ enderson, G. 1969:T hePrecambrian rocks of theEgedesminde-Christianshåb area, West Greenland. Rapport G rønlands G eologiske U ndersøgelse 23, $37 \mathrm{pp}$.

H oldsworth, R.E., Tavarnelli, E., Clegg, P., Pinheiro, R.V.L., J ones, R.R. \& M CC affrey, K.J.W. 2002: Domainal deformation patterns and strain partitioning during transpression: an example from theSouthern Uplands terrane, Scotland. J ournal of the Geological Society (London) 159, 401-415.

Kalsbeek, F. \& N utman, A.P. 1996: Anatomy of the Early Proterozoic $\mathrm{N}$ agssugtogidian orogen, West $\mathrm{G}$ reenland, explored by reconnaissance SH RIM P U -Pb dating. G eology 24, 515-518.

Kalsbeek, F., Pidgeon, R.T. \& Taylor, P.N . 1987: Nagssugtogidian mobile belt of West Greenland: a cryptic $1850 \mathrm{M}$ a suture between two Archaean continents - chemical and isotopic evidence. Earth and Planetary Science Letters 85, 365-385.

M anatschal, G ., U lfbeck, D . \& van G ool, J.[A.M .] 1998: C hangefrom thrusting to syncollisional extension at a mid-crustal level: an examplefrom the Palaeoproterozoic N agssugtogidian orogen (West Greenland). Canadian Journal of Earth Sciences 35, 802-819. 
M arker, M ., M engel, F., van Gool, J.[A.M .] \& field party 1995: Evolution of the Palaeoproterozoic N agssugtogidian orogen: D LC investigations in West $\mathrm{G}$ reenland. Rapport Grønlands G eologiske U ndersøgelse 165, 100-105.

M engel, F., van G ool, J.A.M ., Krogstad, E. \& the 1997 field crew 1998: Archaean and Palaeoproterozoic orogenic processes: $D$ anish Lithosphere $C$ entre studies of the Nagssugtogidian orogen, West Greenland. G eology of Greenland Survey Bulletin 180, 100-110.

N oeN ygaard, A. \& Ramberg, H . 1961: G eological reconnaissancemap of the country between latitudes $69^{\circ} \mathrm{N}$ and $63^{\circ} 45^{\prime} \mathrm{N}$, West G reenland, 1:500 000. G eological M ap Grønlands Geologiske Undersøgelse 1, 9 pp., 2 maps. (Also M eddelelser om G rønland 123(5).)

Piazolo, S., Alsop, G.I., van Gool, J.[A.M .] \& Nielsen, B.M. 2004: U sing GIS to unravel high strain patterns in high grade terranes: a case study of indentor tectonics from West G reenland. In: Alsop, G.I. et al. (eds): Flow processes in faults and shear zones. Geological Society Special Publication (London) 224, 63-78.

Ramberg, H . 1949: On the petrogenesis of the gneiss complexes between Sukkertoppen and C hristianshaab, W est Greenland. M eddelelser fra D ansk Geologisk Forening 11, 312-327.
Thrane, K. \& Connelly, J.N . 2006: Zircon geochronology from the $K$ angaatsiaq- $Q$ asigiannguit region, the northern part of the 1.9$1.8 \mathrm{Ga} \mathrm{N}$ agssugtogidian orogen, West $\mathrm{G}$ reenland. In: G arde, A.A. $\&$ Kal sbeek, F. (eds): Precambrian crustal evolution and $C$ retaceousPalaeogene faulting in West $G$ reenland. G eological Survey of D enmark and $G$ reenland Bulletin 11, 87-99 (this volume).

van Gool, J.A.M ., Kriegsman, L., M arker, M . \& N ichols, G.T. 1999: Thrust stacking in the inner N ordre Strømfjord area, West G reenland: significancefor the tectonic evolution of the Palaeoproterozoic Nagssugtogidian orogen. Precambrian Research 93, 71-86.

van Gool, J.A.M . et al. 2002a: Precambrian geology of the northern $N$ agssugtogidian orogen, West Greenland: mapping in the Kangaatsiaq area. G eology of G reenland Survey Bulletin 191, 13-23.

van Gool, J.A.M., Connelly, J.N ., M arker, M . \& Menge, F.C. 2002b: TheN agssugtogidian orogen of West $G$ reenland: tectonic evolution and regional correlations from a West $\mathrm{G}$ reenland perspective. Canadian J ournal of Earth Sciences 39, 665-686.

Wegmann, C.E. 1935: Zur D eutung der Migmatite. GeologischeRundschau 26, 305-350. 